\title{
Interview with David Lewis, Director of Corruption Watch
}

\author{
Chandré Gould speaks to David Lewis, ${ }^{\star}$ Director of Corruption Watch, ${ }^{1}$ a new non-governmental \\ organisation in South Africa that has thrown its weight behind efforts to reduce corruption.
}

Chandré Gould (CG): Corruption Watch is the newest NGO on the block in South Africa. Could you tell me a bit about the organisation, who established it, and what you hope to achieve?

David Lewis (DL): The idea for Corruption Watch was initiated in a conversation that Zwelinzima Vavi [head of the trade union movement COSATU] and the COSATU office bearers held a couple of months ago to talk about the steady stream of whistle-blowing complaints that COSATU head office was receiving.

These were coming mostly from COSATU's members, but also from members of the public. This had arisen largely, I think, from the very outspoken stance that COSATU had taken on the question of corruption and from some very successful hits that they had had on corruption, the SAA one probably being the best known. ${ }^{2}$ COSATU itself has taken some severe hits as a result of their whistleblowing, the most notorious being the assassination of union leader, Moss Phakoe. The former mayor of Rustenburg, the mayor's driver, a member of the mayoral committee and a local businessman are presently on trial, charged with his murder. COSATU

* David Lewis, who is trained as an economist, worked in the trade union movement throughout the 1970s and 1980s. Since 1994 he has worked in various positions in the public service, most recently serving two terms as Chairperson of the Competition Tribunal from 19992009. wanted to respond to these complaints and to do something about them. There was a need for someone to take these allegations and look at them.

We quickly recognised that this needed an institutional response rather than some sort of ad hoc processing of complaints. And so the idea of setting up an institution was born. To arrive at this point has taken some time. For the last six to eight months we've been doing all the things that it takes to set up an institution: from raising the money to buying the desks and chairs. In the process the idea mutated and grew and has changed quite considerably since the original conception.

CG: Who is providing the funding for Corruption Watch?

DL: South African philanthropic foundations, private family foundations. We have some funding from international foundations including the Open Society Foundation and the Sigrid Rausing Trust, foundations who have supported similar efforts in South Africa and around the world. We've had some seed money from COSATU and from Business Leadership South Africa, and some money from South African corporations. Not as much as I'd hoped for, but I hope we might get more.

CG: It is nice to know that your funding is coming from South African sources. I think it's important 
South African NGOs make a shift away from relying on external donors.

DL: Yes, we really didn't want to. We've not approached foreign governments for aid money, although we might in the long term. But I really do like the idea that we are principally funded by an array of South African sources.

CG: You are essentially a single-issue NGO; your primary role is to take complaints about corruption and to receive reports from whistleblowers. But the fact that COSATU thought that this was important enough an issue to establish an institution like Corruption Watch seems to suggest that that you feel that corruption is South Africa's single most important problem. Would that be your analysis?

DL: How do you place corruption against poverty, against unemployment or any other important social problem? I would be uncomfortable with constructing a hierarchy of concerns, but corruption is a huge concern. In fact, I don't think corruption and poverty are unrelated.

I was struck by a very eloquent statement by Deputy President Kgalema Mothlante who was the keynote speaker at the Ruth First memorial lecture a few months ago. He said that second to racism, corruption is the most serious problem that we face. More recently, Jeff Radebe said at the launch of Corruption Watch that corruption is as serious a problem as racism was during apartheid.

There is widespread concern about corruption in South Africa. It is sometimes suggested that this is a suburban kind of concern. But, judging from the thousands of SMSes, e-mails, Tweets, and website postings that we've received, it's clear that's not the case at all. If anything, people in townships, in the rural areas, in the low-income areas see the consequences of corruption much more starkly than people in the suburbs do. So, yes, I think it's a huge national concern. Its equation with racism is accurate. Corruption affects everyone; it cuts across class, race, urban and rural.
However, I find myself wishing that it were quite as focused an area as we might have thought it was. Nevertheless, I feel it is important that NGOs have a single focus. I think that in some ways the most successful institutions, successful NGOs, have benefited from having a single focus, such as the Treatment Action Campaign. But I'm beginning to understand that [corruption] is quite a wide single focus.

CG: I'm glad that you raise the issue of racism, because I think one of the reasons I would see it as important that an organisation like Corruption Watch makes it very clear that this is a concern for all South Africans. Very often the conversation that is held in the media about corruption comes across as somewhat self-righteous. And perhaps even racist. How do we get away from having a selfrighteous conversation about corruption?

DL: I think by having an inclusive conversation. I'm not sure I agree that the media coverage comes across as self-righteous. They are deservedly, and not inappropriately, standing in judgment of those whom they have discovered to be, in their view, at fault. So there's almost a necessary or inevitable element of self-righteousness to it. But I think that this is not a racist concern.

Initially I was very worried, for example about our Facebook page and about our reliance on an Internet platform for hearing complaints. I was concerned that it would show the divide between those who are Internet connected and those who are not. That obviously has a racial dimension to it. I was worried that we would become one of those sites that people use to whine about the 'good old days', or whine about the current government, forgetting the levels of corruption we experienced under apartheid. But that has just not been the case. Ninety-five percent of our respondents on Facebook are black. And on the short-code SMS I think it's probably close to a hundred percent. So I think that sometimes corruption is conveniently presented as a racist issue.

CG: We saw through the public hearings that are were held around the State Information Bill, that there is a desperate need for people to feel as 
though they are being heard by the state on bread and butter issues. And so the discussion about the Bill turned into a discussion about bread and butter issues. Do you find the same thing happening with your complaints?

\section{DL: Definitely. I don't know whether this is} requires a process of public education, or better communication, to inform people more accurately than we've done up to now, about what corruption is. It's not always easily definable by any stretch of the imagination. I think that many believe that any unfair treatment is corrupt. The complaints that weve been getting cover all issues: from domestic abuse to police brutality to piles of industrial relations-related complaints, to consumer complaints, about banks and cellphone companies, amongst others. So it's clear that people are dying for a place they can take their problems to.

We're trying to reach out to fellow NGOs to sign up as part of a network so that we can collectively respond to those complainants, or have a referral network for complaints we can't attend to. The network should include advice centres, lawyers, human rights institutions and state institutions that are meant to deal with particular complaints. And perhaps partly because we have made a strong point of saying that we're as concerned with private sector corruption as we are with public sector corruption, people have come to think that means that we are concerned with their relationship with suppliers or firms that they purchase from. But we're interested in private sector activity to the extent that it abuses public resources.

\section{CG: So when you get a corruption-related complaint, what do you do about it?}

DL: It's a long answer, I'm afraid. At the outset we started with the idea of responding to allegations of individual acts of corruption that COSATU was receiving. We thought that our principal activity would be investigating individual acts of corruption. Given my experience at the Competition Tribunal I know how difficult it is to do investigations of complex allegations; even if you do have policing powers, subpoena powers and search and seizure powers as the Competition Tribunal has, and the police have. But that's what we thought we were going to do. We had in mind a kind of civil society shadow police force that would investigate allegations we received, up to the point that we could take them and pass them on to the Public Protector or to the police. The advantage would be that we could follow up and monitor the actions of these bodies. The idea was that we would then be in a better position to demand answers from the authorities, and maybe from individual citizens. That's going to remain an important part of our activity. People equate dealing with corruption with sending people to jail. And I think that that's right. We'll try and assist that process to the extent that we're able to. And I think we'll be able to do it to a significant extent, but we're going to have to be very selective in what we take on. We're going to have to work closely with the law enforcement authorities to do that.

That said, I think that we're coming to see ourselves as an organisation for mobilising the South African public to speak about their experiences of corruption. We'll collectivise that voice. We'll bring together those complaints, information we receive from the public, and from public domain material like the Auditor General's reports, from research institutions like the ISS, from the media, and we'll collect those complaints. We'll analyse them, we'll pattern them, we'll identify hot-spots of corruption, if you like.

It might be, for example, complaints about corruption in housing in Tembisa, or it might be corruption in the health care sector, and so on. We'll feed that information back to the public, using both our own communications mechanisms as well as the media, mainstream media as well as community media, in a manner that is politically useful. By political I mean it will give people the opportunity to act collectively against a systemic problem.

We've had a lot of complaints about traffic cops. We're soon going to release a study on the 
Johannesburg Metropolitan Police Department, drawing on the work that ISS has done before us. We'll release that report together with all the complaints that we received. We'll ask people to respond to the report and to the solutions that we propose. We will follow that up with a campaign for the rectification of those problems.

Similarly, we're going to do a report on the health care sector, as we've received a lot of complaints related to that sector. Again we'll ask the public to respond to the report and will take the report to stakeholders. The stakeholders might be a residents' association in Tembisa if we're dealing with housing problems there, or it might be a medical association or nurses associations, or trade unions, or companies, or policy experts in a particular area, like health care. We will ask them to respond to what we've written, to tell us where our findings are wrong or accurate; to point to things that we may have missed, and to solutions that we may not have considered. I hope we'll even attract international responses on the website that will lead to sharing of experiences in other countries as well.

We want to be a crowd sourcing platform where people can speak to each other and where they can speak to those in power.

One of the challenges is, I think, that it's going to be difficult to measure our progress and estimate our impact. But we're working on that.

CG: I think, in fact, one can spend too much time trying to do that. It can become one's raison d'etre in the end and can even distract from the work. I think organisations have to be very careful about keeping a balance between doing the work that needs to be done, and measuring our impact and progress. Organisations like ourselves are working in a field where it is often very difficult to measure impact, and where perverse incentives very easily arise out of measuring impact.

Turning now to another matter, what do you believe is the cause of the serious problem of corruption that we have right now? We know we had corruption in the past, it's nothing new; we know that most states around the world face some level of corruption. How bad is our problem in comparison to other countries? And how and why have we reached the point where an organisation like Corruption Watch is necessary?

DL: I think you're dealing here not with an ordinary problem of criminality, but with a problem on a scale that is beyond ordinary levels of criminality. You're dealing with a real social problem. And so no matter how strong your policing and enforcement mechanisms are, or how well they work, you need a public voice on this issue. Corruption is a kind of grey area. It's not always criminal. But it always offends against public norms and public perceptions of what is appropriate conduct. What is the cause of it? Are we worse off than anywhere else?

That doesn't seem to really matter, because the public are sufficiently worried about it for it to be conversation $d u$ jour in South Africa, across dining room tables in Sandton and kitchen tables in much poorer areas. Quite clearly, on most of the measures we are not doing well and we are sliding down the scale. Yesterday somebody from the International Marketing Council told me that a year ago the biggest stain on South Africa's reputation abroad was violent crime. Now it's corruption. That's something to worry about. So whether we're better off than Russia or worse off than France, or whatever the case may be, doesn't seem to really matter. The fact is we have a big problem, and its getting worse. This is the perception internationally and nationally.

How did we get there? That is a difficult question to answer, both politically and factually. I was struck when I was fund raising outside the country and speaking to people who really knew and understood the field internationally. They pointed out that we had all the ingredients for a country that should not be very corrupt. We have an independent judiciary, we have a robust media, we've had an active civil society, we have a strong constitutional underpinning to our democracy, and so on. These were all the ingredients that they were suggesting to other countries that were corrupt; things they needed to 
have in place in order to staunch corruption. Yet they have not had that effect here. So I don't know the definitive answer to that question.

I think it has something to do with the way in which business and government interact, which has interesting historical roots. It is also a consequence of contemporary policy, which may be well-intentioned and necessary, but which has had the unintended effects of making political connectedness an important part of doing business. This has encouraged a significant degree of corruption.

I also think that to some extent a lack of political competition is responsible for high levels of corruption. Put simply, if a corrupt business or a corrupt politician can take a relatively sure bet on who the next government will be, whether at local, provincial or a national level, then it's worthwhile investing heavily in the consequences that follow from it. You know who will have control of the public resources with relative certainty, and so you ensure that you develop a relationship with the right people. This is not rocket science.

People like Gwede Mantashe (General Secretary of the ANC) and others - including Zwelinzima Vavi himself - have publicly bemoaned the fact that ANC factions are increasingly divided around access to public resources rather than on ideological grounds. So while it's not our remit to change the political framework, the strength of the ANC means that it has a difficult task in terms of countering corruption. Because they are strong, I think their rule is certain, and they're perfectly entitled to keep it, but one of the consequences is that unscrupulous politicians and businessmen and civil servants will take advantage of the certainty in our political system.

CG: David, I think we have to leave it there. Is there anything you would like to say in conclusion?

DL: Yes, we're a small organisation. We're always going to be a small organisation. We're going to always be under-resourced relative to the scale of the problem that we're dealing with. And so our model critically depends on our having good relations with the media, to leverage the knowledge that hopefully we derive from our communications model. But even more importantly will be our ability to establish and maintain relations with other NGOs and with other state bodies and constitutional bodies. And so we want to become part of creating a network. I'm aware that we are the newest kid on the block, as you put it, and if many of these networks exist we want to join them and take advantage of them. I don't think fifteen people in the office in Rosebank can, on their own, make an impact on the problem.

CG: That makes sense, but the truth is that there's been a dramatic erosion of NGOs over the last ten, fifteen years. There are not that many NGOs working in this kind of field any longer. My feeling is that one of the problems we face, the reason why people feel as though their voices aren't heard about bread and butter issues, is that we no longer have advice offices. We no longer have paralegals to the same extent as they existed in the heyday of Black Sash and Lawyers for Human Rights. And so those avenues for citizens to share and get assistance to resolve their concerns have dried up.

DL: Yes, but they're starting up again, but under difficult circumstances. The funding situation is difficult, but I think they are starting up again. And I think that's probably one of the causes of corruption that I should have identified. After hundreds of years of fighting minority rule, we all sat back a bit after 1994. Whether we came from the trade union movement or from the advice office movement, we thought, well great, we've got a decent government now, and that is true, but any government has to be held accountable. And if citizens don't hold it accountable, it will go the way of all institutions that are not accountable to anybody. And so I think South Africans have woken up. I think government has woken up. But in the meantime we've allowed corrupt people to become entrenched in important positions. We've allowed rules to deteriorate and cease to be enforced. But it is not too late. 


\section{NOTES}

1. Corruption Watch can be contacted through its website: http://www.corruptionwatch.org.za/

2. A dossier prepared by the shop stewards and their union, SATAWU, eventually resulted in the company parting ways with the CEO and the appointment of a new board of directors. 